\title{
Performance of Plantain (Musa Paradisiaca L) Fruit Yield and Quality under Different Planting Densities and Water Application
}

\author{
${ }^{1}$ Murphy Kayode M., ${ }^{2}$ Ozigbo Emmanuel S., and ${ }^{3}$ Adunoye Francis O. \\ 1,2,3, International Institute of Tropical Agriculture, Ibadan, Nigeria.
}

\begin{abstract}
The performance of plantain fruit yield and quality under different planting densities under an influence of irrigation system was investigated at International Institute of Tropical Agriculture, Ibadan, Oyo State, Nigeria. Experiments were set up as a split plot fitted into randomized complete block design (RCBD) with three replications. Main plots are irrigation system while sub-plots are plant densities. Treatments included four plant densities $(1 \times 2,2 \times 2,2$ $x 3$, and $3 \times 3 \mathrm{~m}$ ), two irrigation systems and their combination where irrigation system was the main plot and plant density the sub-plot. Over 2,000 agbagba suckers were pared and hot-water treated, and planted during the first week of the experiment. Manure was applied at the rate of three spades full per plant for nutrient supplement; and mulching was done. Weeds were manually controlled as at when due. Plantain diseases like yellow sigatoka and black sigatoka were also controlled manually by de-leafing infected leaves to prevent disease spread. Data were collected and analyzed using ANOVA. Duncan multiple range test (DMRT) was used for mean separation at 5\% level of significance. The results of ANOVA showed that there were significant effects $(P<0.05)$ due to irrigation application for all measured parameters whereas effects due to plant densities were significant for only these parameters; number of suckers (NOS), sucker height (SUHT), number of leaves on sucker (NLSC), bunch weight (BWT), number of hand (NHND), total number of finger (TFNG) and number of sucker at flowering (NSCK). Therefore, it can be concluded that plant spacing, and regular water supply plays a significant role in obtaining good yield in plantain production.
\end{abstract}

Keywords:- Plantain, Fruit Yield, Quality, Irrigation and Planting Density

\section{INTRODUCTION}

Plantain (Musa paradisiaca L.) belongs to the family of Musaceae and the genus of Musa, a tree like perennial; it grows up to 2-9 inches tall, with an underground rhizome (Makanjuola et al., 2013). According to Okareh et al (2015), 100g edible portion of plantain to contain $67.30 \mathrm{~g}$ moisture, $0.4 \mathrm{~g}$ crude fat, $31.15 \mathrm{~g}$ carbohydrate, $0.95 \mathrm{mg}$ potassium, $35.1 \mathrm{mg}$ sodium, $71.5 \mathrm{mg}$ calcium, $28 \mathrm{mg}$ phosphorus, $2.4 \mathrm{mg}$ iron, and yield $116 \mathrm{kcal}$ of energy. He further argued that the wastes contained between 9.39 and
$9.53 \mathrm{~g}$ moisture, 1.87 and $19.37 \mathrm{~g}$ crude protein, 0.73 and $1.83 \mathrm{~g}$ crude fat, 8.10 and $15.50 \mathrm{~g}$ crude fibre and 54.00 and $68.00 \mathrm{~g}$ carbohydrate/100 g sample. Nigeria is known to be the world's largest producer and consumer of plantain (10.5 million tonnes per annum), accounting for approximately $10 \%$ of total global production (FAOSTAT, 2006). Thus, plantains contribute significantly to food and income security of people engaged in its production and trade, particularly in Nigeria and some developing countries of the world. Plantain is a major starchy staple in the subSaharan Africa (SSA) being consumed by both for rural and urban populace, providing more than $25 \%$ of the carbohydrates and $10 \%$ of the daily calorie intake for more than 70 million people in the continent (Ogidi et al., 2017).

Various breeding studies have been conducted on Musa species; breeding and genotype $\mathrm{x}$ environment $(\mathrm{G} x$ E) modeling (Shaibu et al., 2013) and assessment of agronomic performance of diploids and tetraploids and phenotypic diversity within different plantain germplasms have been documented (Shaibu et al., 2012). The cultivation of plantain is underexploited due to inadequate provision of good quality planting materials for propagation. The new technology of sucker multiplication has met with great success among small-scale farmers because it is relatively easy to produce large numbers of plantlets in a short time thereby reducing challenges faced by farmers on planting materials. One sucker can produce between 10 and 50 plantlets, depending on the variety of plantain and the experience of the farmer (Ngo-Samnick, 2011).

Plant density, has a great influence on growth and development of every crop. Due to competition for sun light generated within the plant community (Santiago et al., 2017). Management of plant density population is important to control the sun light amount received by the crop. Also, according to N'guetta et al (2016), high planting density can control soil moisture loss and weed occurrence in the field because of the important canopy. Generally, higher yields per area unit as a result of efficient sun light use are obtained during the early stages of crop growth. However, with high densities, agronomic performance of plantain crop can decrease by sun light competition, excessive water loss through transpiration and plant pest and disease (Santiago et al., 2017). It was reported in Husameldin and Mohammed (2014) that thigh planting density may increase soil nutrient exportation as 
well as moisture requirement of crop. The development of off-season cropping of plantain may have response to seasonal shortage especially, when applying high planting density as observed in many other countries (N'guetta et al., 2015).

\section{METHODOLOGY}

\section{$>$ Background of the Study}

The study was conducted at International Institute of Tropical Agriculture (IITA), Ibadan station in Nigeria. IITA is located at $7^{\circ} 30^{\prime} 8^{\prime \prime} \mathrm{N}$ latitude, $3^{\circ} 54^{\prime} 37^{\prime \prime} \mathrm{E}$ longitude at an elevation of $248 \mathrm{~m}$ above sea level in the forest-savannah agro-ecology. The soil type is Alfisol clay loam, and soil pH of 5.0 - 6.5. Plantain suckers of Agbagba variety selected at IITA Ibadan were used for this study. The field and planting materials were organized to reflect homogeneity in sucker size and weight.

\section{Experimental Design}

Experiments were set up as a split plot fitted into randomized complete block design (RCBD) with three replications. Main plots are irrigation systems while subplots are plant densities. Treatments included four plant densities, two irrigation systems and their combination where irrigation system was the main plot and plant density the sub-plot. One hectare of land ( $1 \mathrm{ha}$ ) was demarcated into three (3) irrigated and three (3) non-irrigated plots. Each main plot was subdivided into four (4) sub-plots for the different planting densities $(1 \times 2,2 \times 2,2 \times 3$, and $3 \times 3$ $\mathrm{m})$. Each sub-plot was planted with experimental plants, surrounded by border plants between sub-plots and around outside borders of the plots. Over 2,000 agbagba suckers were pared and hot-water treated, and planted during the first week of the experiment. Manure was applied at the rate of three spades full per plant for nutrient supplement; and mulching was done. Weeds were manually controlled as at when due. Plantain diseases like yellow sigatoka and black sigatoka were also controlled manually by de-leafing infected leaves to prevent disease spread.

\section{Data Collection}

Data were corrected and recorded on plot basis as follows: date of flowering (DOF) was taken as a day of flower emergence after the last leaf; days to flowering (DTF) was taken as the number of days from planting to flowering; plant height (PLHT) was taken from the base of the plant to the last V of the plant; girth of plant (GT100) was taken at $100 \mathrm{~cm}$ from the ground level with a meter rule; girth of plant at plant base (GTBASE) was taken at the ground level with a meter rule; total number of leaves (TNL) was taken by counting from the top; bunch weight (BWT) was measured with weighing scale; total number of fruit (TNF) was taken by counting from top hand to the last hand; sucker height (SUHT) was measured from the base of the sucker to the last $\mathrm{V}$ shape of the leaf for the oldest sucker; number of hand (NHND) was taken by counting of the number of hands on a bunch; total number of finger (TFNG) was taken by counting of the total fingers per bunch; finger weight (FGWT) was taken as the average weight of fingers in a bunch; finger length (FGL) was taken as the average length of fingers in a bunch; finger weight (FGW) was taken as the weight of the middle finger of the second hand of each bunch; total number of leaves at harvest (LFHVT) was taken by counting of the number of leaves on a plant at harvest; youngest leaf spotted at harvest (YLSHVS) is the sigatoka infection on the leaf taken as the number of leaves infected with sigatoka per plant at harvest; young leaf spotted (YLS) is the sigatoka infection on the leaf taken as the number of leaves infected with sigatoka per plant at flowering; number of Suckers (NSCK) was taken at flowering; number of suckers (NOS) was taken at harvest and Days to harvest (DTH) was taken and recorded.

\section{Statistical Analysis}

Data collected were subjected to analysis of variance (ANOVA). Duncan multiple range test (DMRT) was used for mean separation at $5 \%$ level of significance.

\section{RESULTS}

\section{Effects of the Planting Densities on the Plantain Fruit Yield Quality}

The result of the table 1 below shows that there was a significant variation at $\mathrm{P}<0.05$ level observed on the effect of the plant densities on only the following plantain fruit yields parameters: number of suckers (NOS), sucker height (SUHT), number of leaves on sucker (NLSC), bunch weight (BWT), Number of hand (NHND), total number of finger (TFNG) and number of sucker at flowering (NSCK).

\begin{tabular}{|c|c|c|c|c|c|c|c|c|c|c|}
\hline $\begin{array}{l}\text { SOURCE OF } \\
\text { VARIATION }\end{array}$ & df & PLHT & NOF & GT100 & $\begin{array}{c}\text { GTBAS } \\
\text { E }\end{array}$ & NOS & SUHT & $\begin{array}{c}\text { NLS } \\
\mathbf{U}\end{array}$ & YSL & BWT \\
\hline Irrigation & 1 & $\begin{array}{c}38973.14 * \\
*\end{array}$ & $\begin{array}{c}1019.3^{*} \\
*\end{array}$ & $\begin{array}{c}1143.8^{*} \\
*\end{array}$ & $1300.9 * *$ & $18.0 *$ & $38.1 * * *$ & $\begin{array}{c}50.7 * \\
*\end{array}$ & $\begin{array}{c}39.4 * \\
*\end{array}$ & $\begin{array}{c}130.8^{*} \\
*\end{array}$ \\
\hline Rep(Irrigation) & 4 & $1764.4 \mathrm{~ns}$ & $6.6 \mathrm{~ns}$ & $34.3 \mathrm{~ns}$ & $60.2 \mathrm{~ns}$ & $0.7 \mathrm{~ns}$ & 192.0ns & $2.7 \mathrm{~ns}$ & $0.2 \mathrm{~ns}$ & $2.8 \mathrm{~ns}$ \\
\hline Density & 3 & $1750.6 \mathrm{~ns}$ & $40.2 \mathrm{~ns}$ & $148.7 \mathrm{~ns}$ & $216.3 \mathrm{~ns}$ & $\begin{array}{c}21.7 * \\
*\end{array}$ & $\begin{array}{c}3249.9 * \\
*\end{array}$ & $\begin{array}{c}30.6^{*} \\
*\end{array}$ & $4.9 \mathrm{~ns}$ & $22.6^{*}$ \\
\hline Irrigation*Density & 3 & $857.6 \mathrm{~ns}$ & $6.1 \mathrm{~ns}$ & $27.2 \mathrm{~ns}$ & $41.4 \mathrm{~ns}$ & $2.4 \mathrm{~ns}$ & $280.5 \mathrm{~ns}$ & $1.7 \mathrm{~ns}$ & $0.1 \mathrm{~ns}$ & $0.1 \mathrm{~ns}$ \\
\hline Error & $\begin{array}{l}1 \\
2\end{array}$ & 2173.7 & 36.0 & 50.9 & 94.9 & 3.0 & 481.8 & 3.1 & 1.94 & 5.1 \\
\hline
\end{tabular}

$* * *=$ Data significant at $\mathrm{P}<0.0001, * *=$ data significant at $\mathrm{P}<0.001, *=$ data significant at $\mathrm{P}<0.05 \mathrm{~ns}=$ not significant at $\mathrm{P}<$ 0.05

Table 1:- Planting Densities Variations versus Fruit Yield Parameters of Plantain 
ISSN No:-2456-2165

\begin{tabular}{|c|c|c|c|c|c|c|c|c|c|}
\hline SOURCE OF VARIATION & Df & NHND & TFNG & FGWT & FGL & FGW & NSCK & LFHVT & YLSHVT \\
\hline Irrigation & 1 & $14.7^{* *}$ & $209.7^{*}$ & $142371.4^{* * *}$ & $917.8^{* *}$ & $168.4^{* *}$ & $23.9^{*}$ & $4.0^{*}$ & $0.6^{*}$ \\
\hline Rep(Irrigation) & 4 & $7.1 \mathrm{~ns}$ & $167.7 \mathrm{~ns}$ & $3205.4 \mathrm{~ns}$ & $33.5 \mathrm{~ns}$ & $4.5 \mathrm{~ns}$ & $1.1 \mathrm{~ns}$ & $0.5 \mathrm{~ns}$ & $0.1 \mathrm{~ns}$ \\
\hline Density & 3 & $10.7^{*}$ & $548.2^{* *}$ & $9767.9 \mathrm{~ns}$ & $76.2 \mathrm{~ns}$ & $13.1 \mathrm{~ns}$ & $36.1^{*}$ & $0.5 \mathrm{~ns}$ & $0.2 \mathrm{~ns}$ \\
\hline Irrigation*Density & 3 & $1.5 \mathrm{~ns}$ & $37.6 \mathrm{~ns}$ & $398.4 \mathrm{~ns}$ & $0.3 \mathrm{~ns}$ & $0.3 \mathrm{~ns}$ & $2.3 \mathrm{~ns}$ & $0.06 \mathrm{~ns}$ & $0.02 \mathrm{~ns}$ \\
\hline Error & 12 & 11.8 & 25.9 & 3881.8 & 35.5 & 6.4 & 2.9 & 0.5 & 0.1 \\
\hline
\end{tabular}

$* * *=$ Data significant at $\mathrm{P}<0.0001, * *=$ data significant at $\mathrm{P}<0.001, *=$ data significant at $\mathrm{P}<0.05 \mathrm{~ns}=$ not significant at $\mathrm{P}$ $>0.05$

Table 1:- Planting Densities Variations versus Fruit Yield Parameters of Plantain (Continued)

Effects of the Irrigation and Non Irrigation Applications on the Fruit Yield

The results of ANOVA analyzed in table 2 below showed that there were significant effects $(\mathrm{P}<0.05)$ due to artificial application of water for all measured plantain fruit yield parameters: days to flowering (DTF), plant height (PLHT), girth of plant (GT100), girth of plant at plant base (GTBASE), total number of leaves (TNL), bunch weight (BWT), total number of fruit (TNF), sucker height (SUHT), number of hand (NHND), total number of finger (TFNG), finger weight (FGWT), finger length (FGL), finger weight
(FGW), number of leaves at harvest (LFHVT), and youngest leaf spotted at harvest (YLSHVS), young leaf spotted (YLS), number of Suckers (NSCK), number of suckers (NOS), Days to harvest (DTH).

The figure 1 below shows that average mean values of the yield parameters of the experiment under the irrigated and non-irrigated conditions. The graph presented a virtual expression of the fruit yields and possibly their significance level from each other.

\begin{tabular}{|c|c|c|c|c|c|c|c|c|c|c|}
\hline TREATMENT & Density & PLHT & NOF & GT100 & GTBASE & NOS & SUHT & $\overline{\text { NLSU }}$ & YLS & BWT \\
\hline \multirow[t]{4}{*}{ IRRIGATED } & $1 \times 2$ & 304.9 & 35.1 & 46.5 & 63 & 6.6 & 110.1 & 5.3 & 7.3 & 8.6 \\
\hline & $2 \times 2$ & 310.2 & 35.9 & 49.4 & 66.5 & 8.7 & 117.3 & 6.3 & 8.1 & 10.8 \\
\hline & $2 \times 3$ & 323.3 & 39.2 & 53.9 & 70.7 & 10.2 & 154.3 & 9.2 & 8.2 & 11.8 \\
\hline & $3 \times 3$ & 323 & 41 & 55.9 & 73.1 & 10.6 & 160.6 & 9.6 & 9.4 & 13.3 \\
\hline Mean & - & 315.4 & 37.8 & 51.4 & 68.3 & 9.0 & 135.6 & 7.6 & 8.3 & 11.1 \\
\hline NON_IRRIGATED & $1 \times 2$ & 211.1 & 22.3 & 32.3 & 46.1 & 5.3 & 58.3 & 2 & 4.6 & 4.2 \\
\hline \multirow{4}{*}{ Mean } & $2 \times 2$ & 232.9 & 24.8 & 36.9 & 53.1 & 6.6 & 71.8 & 3.8 & 5.8 & 5.7 \\
\hline & $2 \times 3$ & 220.4 & 23.4 & 34.5 & 50.2 & 7 & 78.9 & 5 & 5.5 & 7.2 \\
\hline & $3 \times 3$ & 274.5 & 28.6 & 46.8 & 65 & 10.4 & 112.1 & 7.9 & 6.9 & 8.7 \\
\hline & & 234.7 & 24.8 & 37.6 & 53.6 & 7.3 & 80.3 & 4.7 & 5.7 & 6.5 \\
\hline Mean (Across) & & 275.1 & 31.3 & 44.5 & 61.0 & 8.2 & 107.9 & 6.1 & 7.0 & 8.8 \\
\hline Std Error & & 12.0 & 1.7 & 2.1 & 2.5 & 0.5 & 8.0 & 0.6 & 0.4 & 0.7 \\
\hline CV (\%) & & 16.95 & 19.17 & 16.03 & 15.98 & 21.27 & 20.34 & 28.88 & 20 & 25.76 \\
\hline & & & & & & & & & & \\
\hline
\end{tabular}

Table 2:- Effects of Irrigation and Non Irrigation Applications on the Plantain Yield Quality 
ISSN No:-2456-2165

\begin{tabular}{|c|c|c|c|c|c|c|c|c|c|c|}
\hline TREATMENT & Density & NHND & TFNG & FGWT & FGL & FGW & NSCK & SCHT & LFHVT & YLSHVT \\
\hline \multirow{3}{*}{ IRRIGATED } & $\mathbf{1 x 2}$ & 5.4 & 22.7 & 270.6 & 27.6 & 12.1 & 5.3 & 155.8 & 3.4 & 1.4 \\
\cline { 2 - 12 } & $\mathbf{2 x 2}$ & 5.9 & 26.3 & 333.3 & 31.3 & 13.8 & 6.5 & 172.5 & 3.8 & 1.6 \\
\cline { 2 - 12 } & $\mathbf{2 x 3}$ & 6.4 & 30.4 & 317.2 & 33.4 & 14 & 7.6 & 220.8 & 3.7 & 1.4 \\
\cline { 2 - 12 } & $\mathbf{3 x 3}$ & 6.5 & 32.2 & 365.8 & 35.5 & 15.6 & 8.7 & 234.7 & 3.7 & 1.2 \\
\hline \multirow{3}{*}{ Mean } & - & 6.1 & 27.9 & 321.7 & 32.0 & 13.9 & 7.0 & 196.0 & 3.7 & 1.4 \\
\hline \multirow{3}{*}{ NON_IRRIGATED } & $\mathbf{1 x 2}$ & 3.2 & 14.2 & 112.2 & 14.9 & 6.4 & 3.1 & 66.3 & 2.2 & 0.9 \\
\cline { 2 - 12 } & $\mathbf{2 x 2}$ & 4.2 & 19.7 & 161.1 & 18.7 & 8.6 & 5.4 & 85.3 & 3.1 & 1.3 \\
\cline { 2 - 11 } & $\mathbf{2 x 3}$ & 4.8 & 23.7 & 184.3 & 20.8 & 9.2 & 4.8 & 102.5 & 3.1 & 1.2 \\
\cline { 2 - 11 } & $\mathbf{3 x 3}$ & 5.7 & 30.5 & 213 & 23.8 & 10 & 6.7 & 131.8 & 2.9 & 1 \\
\hline Statistics & & & & & & & & & & 1.2 \\
\hline Mean & & 5.3 & 25.0 & 244.7 & 25.8 & 11.2 & 6.0 & 146.2 & 3.2 & 1.2 \\
\hline Std Error & & 0.3 & 1.5 & 20.5 & 1.8 & 0.7 & 0.4 & 13.3 & 0.2 & 0.1 \\
\hline CV (\%) & & 18.89 & 20.39 & 25.46 & 23.14 & 22.61 & 28.4 & 20.78 & 22.58 & 28.43 \\
\hline
\end{tabular}

Table 2:- Attributes Mean across Irrigation and non Irrigation Applications on the Fruit Yield Quality (Continued)

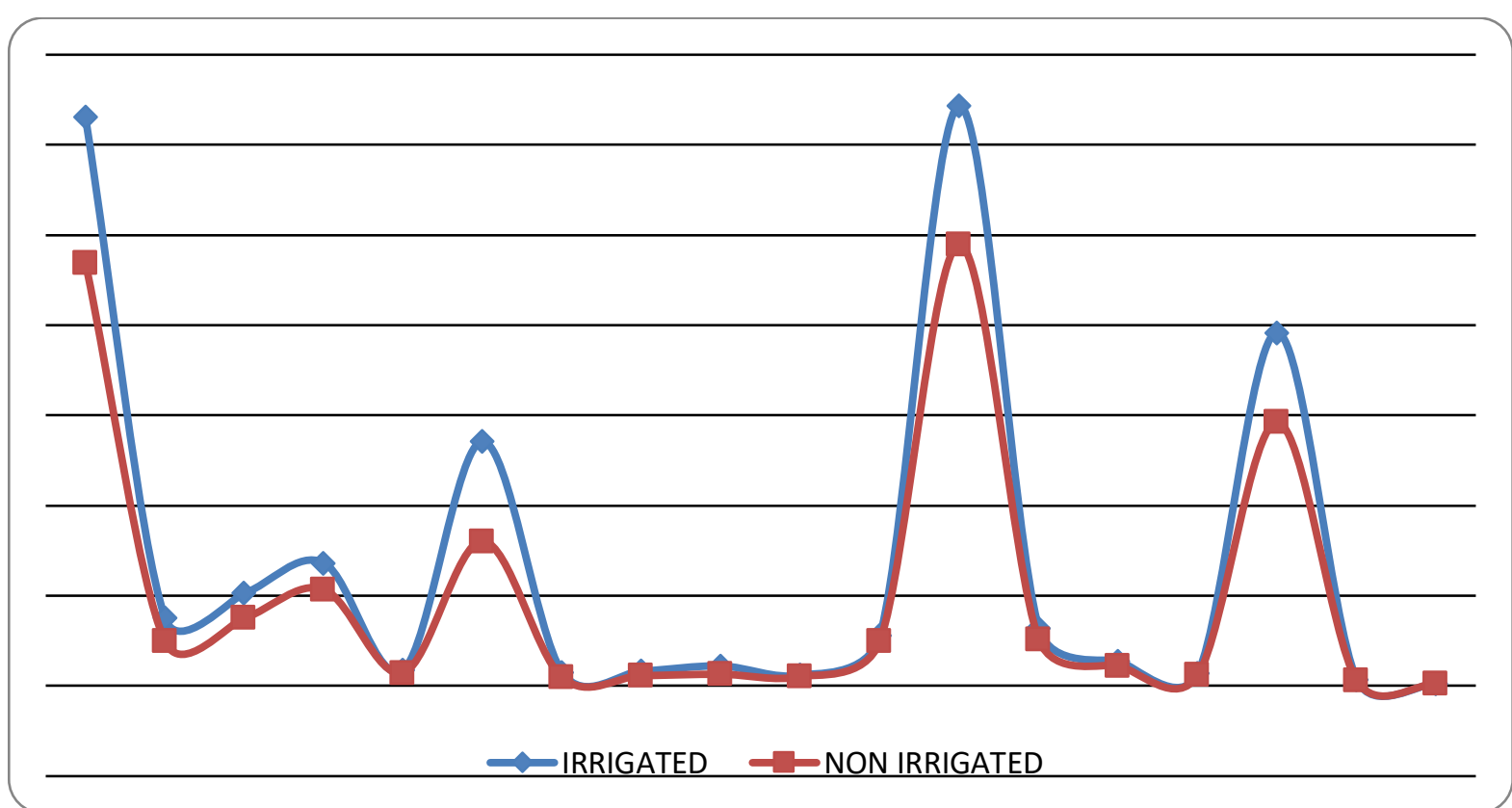

Fig 1:- Mean Values of the Irriagated and Non irragation Area of the Experiment

\section{DISCUSSIONS}

From the table 1 above, it was observed that at $\mathrm{P}>$ 0.05 , the densities of the study had no significant difference on the average mean values of the fruit yield parameters such as PLHT (1750.6), NOF (40.2), GT100 (148.7), GTBASE (216.3), YSL (4.9), FGWT (9767.9), FGL (76.2), FGW (13.1), LFHVT (0.5), and YLSHVT (0.2). Meanwhile, at $\mathrm{P}<0.001$, that the densities significantly affected the fruit yield of the plantain parameters measured: NOS (21.7), SUHT (3249.9), NLSU (30.6), and TFNG (548.2). Also, at $\mathrm{P}<0.05$, there was significant difference noticed on some of the fruit yields parameters due to the effects of densities: BWT (22.6), NHND (10.7) and NSCK
(36.1). This is in accordance with the result reported by Santiago et al (2017) that density has a great effect on the plantain yields as higher densities presented advantages with best average hand weight, AHNDW (14.5 kg) and number of hand, NHND (4.9). Also, Cayon et al (2004) urged that plant density in plantain for a certain variety is determined by the distance between rows and the number of plants, and has a positive or negative effect in the stages development and crop production. More so, according to Belalcazar et al (2003), an increased yield in plantain crop was achieved from 270 to $345 \%$ with densities between 3000 to 5000 plants/ha respectively when compared to conventional plantations with 1000 plants/ha. Santiago et al (2017), further reported that high density plantations had 
lower incidence of yellow sigatoka (Mycosphaerella musicola R. Leach ex J. L. Mulder,) and black sigatoka (Mycosphaerella fijiensis Morelet). He further added that the high densities increase the time to flowering and harvest. But the increase in the number of plants per hectare has direct influence on growth factors and the total yield and a negative effect on production per plant and percentage of harvested plants. In fact, the high planting density can control soil moisture loss and weed occurrence in the field because of the important canopy (Singh et al., 2012).

In table 2 and figure 1 above, at $\mathrm{P}<0.05$, the results show that water application to the plant proportionately affects its fruit yield for all the yield parameters evaluated throughout the experiment. For example, it was observed that plant height of the irrigated areas on the average mean has $315.4 \mathrm{~cm}$ whereas the non-irrigated portions records $234.7 \mathrm{~cm}$; while the SUHT irrigated area has a mean value of $135.6 \mathrm{~cm}$, the non-irrigated was found to have $80.3 \mathrm{~cm}$; FGW irrigated mean is $321.7 \mathrm{~cm}$, its non-irrigated is 244.7 $\mathrm{cm}$; SCHT irrigated is $196.0 \mathrm{~cm}$, non-irrigated is $146.2 \mathrm{~cm}$; FGL irrigated is $32.0 \mathrm{~cm}$, non-irrigated is $25.8 \mathrm{~cm}$; the GT100 irrigated is $51.4 \mathrm{~cm}$, non-irrigated is $37.6 \mathrm{~cm}$; the GTBASE irrigated is $68.3 \mathrm{~cm}$, the non-irrigated is $53.6 \mathrm{~cm}$; NOF irrigated is $37.8 \mathrm{~cm}$, its non-irrigated is $24.8 \mathrm{~cm}$, BWT irrigated is $11.1 \mathrm{~cm}$, non-irrigated is $6.5 \mathrm{~cm}$; NOS is $9.0 \mathrm{~cm}$, non-irrigated is 7.3 ; NLSU irrigated is $7.6 \mathrm{~cm}$, nonirrigated is $4.7 \mathrm{~cm}$; NSCK irrigated is $7.0 \mathrm{~cm}$ while the nonirrigated is $6.0 \mathrm{~cm}$. The result above is in accordance with the findings of Goenaga et al. (2003) who recommended the application of proper irrigation management for plantain and banana production and showing that additional costs incurred as a result of irrigation are being compensated for by improved fruit quality and higher yield. Also, Akinro et al (2012) also proved that irrigation is an important factor in plantain crop production as he stated that the amount of irrigation water applied at the different growth stages of the crop influences the yield especially in the tropics where rainfall amount and distribution are erratic.

\section{CONCLUSION AND RECOMMENDATIONS}

The conducted experiments on the performance of plantain for yield under different planting densities and water application have shown that plantain responds to over population and this was evidenced by the plants with the highest plant spacing performing better than those on lower plant spacing. It was also found out that planting with abundant water supply favours optimum yield in plantain production. Therefore, it is recommended that further experiments should be conducted to determine the absolute water requirements per plant so as to cater for proper irrigation planning especially in dry areas with low rainfall. Also, the optimum spacing for plantain should be further investigated to enable farmers attain competitive yield.

\section{REFERENCES}

[1]. Akinro A. O., Olufayo A. A., and Oguntunde P. G (2012). Crop Water Productivity of Plantain (Musa Sp) in a Humid Tropical Environment. Journal of Engineering Science and Technology Review 5(1) (2012) 19-25

[2]. Belalcázar, S., Rosales, F., \& Espinosa, M. (2003). Altas densidades de siembra en plátano, una alternativa rentable y sostenible de producción. En: Galileo R. \& Rosales, F. (Eds.). Taller Manejo convencional y alternativo de la sigatoka negra, nematodos y otras plagas asociadas al cultivo de musáceas en el trópico:: MUSALAC, INIBAP, Guayaquil-Ecuador. pp 55-63

[3]. Cayón, G., Valencia, L., Morales, H., \& Domínguez, A. (2004). Desarrollo y producción del plátano Dominico-Hartón (Musa AAB Simmonds) en diferentes densidades y arreglos de siembra. Agronom, Colomb , 22(1), 18-22

[4]. Goenaga Ricardo, Heber Irizarry, Bruce Coleman and Eulalio Ortiz (2003). Water requirement of plantains (Musa acuminate $\mathrm{x}$ Musa balbisiana $\mathrm{AAB}$ ) grown under semiarid conditions. Tropical Agriculture 70(1):3-7.

[5]. Husameldin, H.M., \& Mohammed, S.A (2014). Total N, P \& K uptake by main and ratoon banana crop cv. Grand Naine under different levels of planting distances, irrigation and fertigation. International Journal of Advanced Research in Biological Sciences, 1 (9), 283-291.

[6]. Makanjuola Olakunle Moses, Ajayi Adebola Bolade, Mattew Kolawole and Makanjuola John Olarenwaju (2013). The Proximate Composition and Mineral Contents of Three Plantain Cultivars Harvested at Matured Green Level. International Journal of Innovations in Bio-Sciences. ISSN: 2277-2367. Vol. 3 (2), 2013 pp. 23-26.

[7]. N'guetta Adélaïde, Brahima Koné*, Traoré Siaka, Aby N'goran, Yao N'drin Thérèse, Yao-Kouamé Albert, Atsin Guy Olivier and Thiémélé Deless Fulgence (2016). Growth and Yield of Plantain in High Planting Density under Nitrogen and Potassium fertilizers on Ferralsol of Humid Forest. International Journal for Research in Agricultural Research. VOL 2 ISSUE 2 February 2016 Paper 5.

[8]. N'guetta, A., Traoré, S., Yao N. T., Aby, N., YA Koffi, D., Atsin G. O., Vawa Otro, S. T., Kobenan, K., Gnonhouri, G. P., \& Yao-Kouamé, A. (2015). Incidence de la densité de plantation sur la croissance et le rendement du bananier plantain en Côte d'Ivoire: cas de deux hybrides (PITA 3 et FHIA 21) et deux variétés locales (Corne 1 et Orishele). Agronomie Africaine, 27 (3), 213-222.

[9]. Ngo-Samnick E. Lionelle. (2011). Improved Plantain Production. The Pro - Agro Collection. ISBN (CTA): 978-92-9081-477-4, Wageningen, Netherlands. 
[10]. Ogidi I.A, Wariboko C. and Alamene A. (2017). Investigation of Some Nutritional Properties of Plantain (Musa Paradisiaca) Cultivars in Bayelsa State. European Journal of Food Science And Technology Vol.5, No.3, Pp.15-35, July 2017.

[11]. Okareh O.T., Adeolu A.T., and Adepoju O.T (2015). Proximate and Mineral composition of Plantain (Musa Paradisiaca) Wastes Flour; a Potential Nutrients source in the Formation of Animal Feeds. African Journal of Food Science and Technology (ISSN: 2141 - 5455). Vol. 6(2) pp. 53-57.

[12]. Santiago Miguel Ulloa Cortazar, Erick Daniel Wolf and Ignacio Armendáriz González (2017). Effect of plant density on growth and yield in Barraganete plantain ( Musa paradisiaca (L.) AAB cv. Curare enano) for a single harvest cutting in Provincia de Los Ríos, Ecuador. Acta Agron. vol.66 no.3 Palmira July/Sept. 2017

[13]. Shaibu, A.A., E.A. Maji and M.N. Ogburia (2012). Yield evaluation of plantain and banana landraces and their hybrids in humid agro ecological zone of Nigeria. E3 Journal of Agricultural Research and Development Vol. 2 (3). pp. 074-079

[14]. Shaibu, A.A., Okoro, P., Ude, G., Olukolu, B.A., Ingelbrecht, I., Tenkouano, A., Oguria, M.N., Moonan, F., and Dimkpa C. (2013). Genotype by Environment ( $\mathrm{G} \times \mathrm{E})$ Modelling of the Variable Initiation of Parthenocarpy Sensu stricto in Musa: Elucidation of the Environmental Components of Variable Expressivity of Parthenocarpy in Facultative apomictic Musa acuminate Subspecies Microcarpa Model System. Science Domain International, 3(2): 262-276.

[15]. Singh, J., Babar, S., Abraham, S., Venugopalan, M. V., \& Majumdar, G. (2012). Fertilization of High Density, Rainfed Cotton Grown on Vertisols of India. Better Crops 96 (2), 26-28. 